\section{Sir John Reith, Minister of Information}

SIR JoHN REITH, chairman of Imperial Airways, Ltd., has been appointed Minister of Information in succession to Lord Macmillan; the way is thus open to bring into the House of Commons the minister in charge of a department the working of which has been severely criticized ever since it began to function on the outbreak of war. Sir John is perhaps better known as the director-general during 1927-38 of the British Broadcasting Corporation, having been managing director of the British Broadcasting Company which preceded it. Hence he was largely responsible for the guidance and development of the broadcasting service of Great Britain in its early and critical days, when its functions were ill-defined and its merits as a vehicle of entertainment, of news and of education for the masses were much debated.

Before he became associated with broadcasting, Sir John was for a short period general manager of the well-known engineering firm, Wm. Beardmore and Co., Ltd. This followed Government posts in charge of munition contracts after and during the War of 1914-18, in which he served with the Royal Engineers. Sir John is an engineer by profession, having passed through the Royal Technical College, Glasgow, and served a five-years engineering apprenticeship in Glasgow. He is a member of the Institution of Civil Engineers. While his professional knowledge was no doubt of service during his eleven years with the B.B.C., it was his forceful character and administrative ability which were outstanding; these, with his experience of public affairs and the Press, will be invaluable assets in the chief of a young department which is capable of making invaluable contributions to the influence and prestige of Great Britain and to the morale of the people at home.

\section{The British Association}

The General Committee and the Council of the British Association held a joint meeting last week, at which Sir Albert Seward, the retiring president, handed over the chair of the Association to his successor, Sir Richard Gregory. It was reported that, by agreement between the authorities at Newcastle and the general officers of the Association, arrangements for the meeting of the Association which had been appointed to take place in that eity next September were in abeyance, and that a meeting there was not contemplated, save in the event of an early peace.

The Committee of the Association therefore proceeded to a discussion of the desirability and possibilities of a meeting being held, in some modified form, and in some other place. As to desirability, there was general agreement; as to possibilities and places, various suggestions were put forward, and in the upshot the general officers were instructed to make the best arrangements they can for some sort of an abbreviated meeting. Whether as part of such a meeting, or independently, the potential activities of the Division for the Social and International Relations of Science will be taken into consideration. No action has been taken to appoint new sectional officers for the year; but the general officers were instructed to consult those who held such offices last year, and any others whose advice and help would be appropriate.

\section{Scientific Workers and the Armed Forces}

The Ministry of Labour and National Service announces that the operation of the Schedule of Reserved Occupations is being relaxed to enable men at or above the age of reservation in scientific occupations to volunteer in approved cases for service in the Forces. Such men have previously been able to join the Forees in their professional capacity, and the present relaxation of the schedule is designed to enable those whose services are not required in a professional capacity in the Forces or as civilians to volunteer for other forms of service. To secure that scientific workers shall not be withdrawn from civil work to the detriment of the national interest, and that an adequate reserve of scientific workers is maintained for essential services, the Scientific Research Committee of the Central Register Advisory Council will consider applications from volunteers with the view of ensuring that relaxation is granted only in suitable cases. Any reserved scientific worker who wishes to volunteer should apply to the Ministry of Jabour and National Service (National Service Department), Montagu House, Whitehall, s.W.1.

\section{Scientific Workers and the War}

A symposium, organized by the Faculty of Science of Marx House, Clerkenwell Green, London, E.C.1, was held during the week-end of December $30-31$, the title of the meeting being "The Position of Science and Scientists in the War Situation". No adequate assessment of the effect of the war is possible without some knowledge of the economic background, and this was afforded by Maurice Dobb in a paper entitled "The Economics of War Capitalism". It was with this background that the meeting held a discussion on the effects of the war on university research and education, opened by Prof. H. Levy. It was argued that the cost of the social services would be cut, and in this respect, the maintenance of the universities on the present scale would be regarded as an unnecessary luxury, with adverse effects on staff, students, and standards of education. Mr. Roscoe Clarke, in discussing the scientific social services, showed that the incidence of the same problems has been felt in the medical services. The emergency medical schemes have cut right across the normal medical services, already dislocated by the evacuation of schoolchildren. Prof. J. D. Bernal, in the concluding paper, dealt with the status of the man of science. The historical role of science in the development of capitalism was analysed, and the effect of the functions of the scientific worker on his status discussed; at the present time, the existing system cannot use to the full the science it has itself brought into being.

The general tone of the discussion as a whole was that scientific workers are more and more 
beginning to feel dissatisfied with the role of science and its present applications to human welfare, and that a material change, if not a complete break, will have to be made with the present economic system before science can be fully utilized. Concern at the insecurity of their own position in the immediate future is leading scientific workers to the view that a new type of scientific organization, based.on the experience of the trade unions in the defence of the economic and cultural interests of large masses of the population, is becoming necessary.

\section{The Earthquake in Turkey}

As the railway between Sivas and the ruins of Erzinjan has now been repaired, it is possible to add a few more details concerning the Erzinjan earthquake of December 27, 1939 (see NATURE of Jan. 6, p. 13). From Ankara to Sivas and Tokat the damage has been done chiefly to the old and badly constructed buildings made from inferior material, whilst the better ferro-concrete public buildings of recent construction have escaped with cracks and minor damage; but from Tokat and Sivas to Erzinjan there has been practically complete destruction of old and new. The only 'oasis' of lesser damage thus far recorded has been at Kemah near Erzinjan, where some buildings still stand, though 548 buildings were wrecked and nearly 150 casualties caused. It appears probable that Kemah was built on more solid rock than the other towns in the area of approximately 15,000 square miles affected.

In the mountainous district between Amasya and Tokat there are ground fissures 12 yards wide, out of which are said to issue smoke and sulphur fumes and also jets of boiling water. There is as yet no direct news of some five hundred villages to the east of Erzinjan, although efforts are being made to reach them through a countryside covered to a depth of $12 \mathrm{ft}$. in snow. At Niksar, a rock pinnacle fell on the town, doing much damage, and there were few survivors in this place or in fourteen of the neighbouring villages, whilst on the Black Sea coast the towns of Kerasun and Ordu are reported to have suffered the greatest damage.

At Kew Observatory the first waves to arrive did so at 0 h. $3 \mathrm{~m}$. 26s. G.M.T. and the maxima exceeded the limits of registration, the ground movement being greater than one millimeter in amplitude. Several severe after-shocks have occurred as well as hundreds of smaller ones. On January 1 there were seven severe after-shocks at Erzinjan, and a violent shock at 7 a.m. local time at Bergama in the west of Turkey. On January 2 at Yozgad there was a strong shock and 190 houses collapsed, though no casualties are reported. The after-shocks appear now to be decreasing in strength and number. Although the after-shock of January 1 was at Bergama, it is yet uncertain whether the floods in the Brusa and Smyrna districts of Turkey and in the Bilecik Valley (River Sakaria) had anything to do with changes in topography attendant on the earthquakes, nor whether the Kemal Pasha Dams and numerous river bridges were destroyed by the shocks or by the floodwaters, but if the meteorological conditions in the area did not cause the floods, they certainly enhanced them considerably.

\section{Other Recent Earthquakes}

ON December 21, San José (Costa Rica) suffered the most severe earthquake it has known since 1923. Buildings were cracked, including the cathedral, though no casualties are reported. The shock was recorded at Manila, at De Bilt (Holland), where the $P$ wave arrived at $2 \mathrm{lh} .7 \mathrm{~m}$. 10s. G.M.T., and at Kew, where the first of three shocks in rapid succession arrived at $21 \mathrm{~h} .6 \mathrm{~m}$. 51s. G.M.T., the maximum ground amplitude at Kew being $0.42 \mathrm{~mm}$. On December 22, considerable damage is reported to have been caused by earthquake shocks in Costa Rica, though no loss of life or other casualties are reported. These shocks were possibly after-shocks of the earthquake which rocked San José on December 21.

On December 22 also severe earthquake shocks were experienced in the South Sea islands of Molucca. On December 23 and 24 earthquakes and landslides, which were probably caused by the earthquakes. occurred in Java in the East Indies. In addition to the Anatolian earthquake of December 27, further shocks were registered at Kew Observatory on December 25 (2), December 28 and December 29. Further news concerning all these shocks is awaited from the areas concerned and from other seismological observatories. On January 2, early in the day, an earthquake shock was perceptible on the Ionian Island of Zante (Greece), though no damage or loss of life has been reported.

\section{Potatoes in War-time}

Potatoes are one of the most valuable sources of human and animal food in war-time, and it is of the greatest national importance that both the acreage devoted to this crop shall be increased and that the maximum yields shall be obtained. Questions of quality, colour and shape must now take second place and yield be the all-important aim of the grower. The National Institute of Agricultural Botany, Cambridge, has just issued a war-time edition of its Farmer's Leaflet No. 3, in which useful information to this end is supplied. Emphasis is laid on the necessity for using healthy seed, as otherwise attention to cultivation, manuring, etc., is of little value. A number of varieties are recommended for both early and main crops; but it is pointed out that to lift potatoes in an unripe condition is an unwarranted waste of tonnage in a time of emergency. As regards choice of varieties, most of those commonly grown are still recommended, but King Edward should be replaced by a heavier cropping kind such as Arran Banner, Arran Consul, Kerr's Pink, Majestic or Redskin.

The use of unsaleable potatoes for animal feeding is the subject of "Growmore" Leaflet No. 10, issued by the Ministry of Agriculture. All potatoes, whether to be used raw or cooked, should be washed before feeding, or digestive trouble may result. Raw potatoes 